\title{

}

JURNAL PENELITIAN BAHASA, SASTRA, DAN

BUDAYA ARAB

P-ISSN: 2615-7241 | E-ISSN: 2721-480X // Vol. 2 No. 1 | 1-14

† https://ejournal.upi.edu/index.php/alsuniyat/index

\section{ANALISIS KALIMAT PERINTAH (AMR) PADA SURAH YĀSĪN DALAM TERJEMAHAN AL-QUR'AN BACAAN MULIA HBJ}

\author{
Deni Maulana \\ Universitas Islam Negeri Syarif Hidayatullah Jakarta, Indonesia \\ E-mail: maulanadeni09@gmail.com
}

\begin{abstract}
:
This study aims to find out how many forms of the command amr in surah Yāsinn, and what translation techniques are used by HBJ. This research uses descriptive qualitative method with content analysis model. The source of the data in this study is the translation of the Al-Qur'an Bacaan Mulia by HBJ at surah Yãsin. Research shows that the form of amr amounts to 12 which means haqiqi, researchers found seven verses. Spread on verses 11, 26, 45, 61, 64, 79, and 82. While from the form of amr means balāgi means li-irsyād (suggestion) the researcher finds five verses. Spread on verses 13, 20, 21, 25, and 47. Furthermore, the translation technique used by HBJ in surah Yāsīn, literal technique that dominates $80 \%$. While the modulation technique is only $20 \%$.
\end{abstract}

Keywords:

Translation; Command sentences (Amr); Surah yāsīn

\begin{abstract}
Abstrak
Penelitian ini bertujuan untuk mengetahui seberapa banyakkah bentuk perintah amr dalam surah Yāsīn, dan teknik penerjemahan apa sajakah yang digunakan oleh HBJ. Penelitian ini menggunakan metode deskriptif kualitatif dengan model analisis isi. Sumber data dalam penelitian ini terjemahan Al-Qur'an Bacaan Mulia karya HBJ pada surah Yāsīn. Penelitian menunjukkan bahwa bentuk amr berjumlah 12 yang bermakna haqĩqi, peneliti menemukan tujuh ayat. Tersebar pada ayat ke 11, 26, 45, 61, 64, 79, dan 82. Sedangkan dari bentuk amr bermakna balāgi bermakna li-irsyād (saran) peneliti menemukan lima ayat. Tersebar pada ayat ke 13, 20, 21, 25, dan 47. Selanjutnya teknik penerjemahan yang digunakan HBJ pada surah Yāsīn, teknik harfiah yang mendominasi $80 \%$. Sedangkan teknik modulasi hanya $20 \%$.
\end{abstract}

\section{Kata Kunci:}

Penerjemahan; Kalimat perintah (Amr); Surah yāsīn

\section{PENDAHULUAN}

Bahasa Al-Qur'an sangat menawan, begitu menawan dan memukau sehingga karya syi'ir yang sudah ada ternyata tak menandingi nilai sastranya. Syi'ir termasuk dalam karya sastra. Sastra merupakan ekspresi bebas. Sastra bukan sesuatu tanpa aturan dan rumusan. Ihwal tersebut bisa dibuktikan dengan munculnya beragam ilmu sastra yang menandaskan kualitas karya sastra yang dianalisa. Dalam tradisi ilmu sastra Arab ada yang dikenal dengan istilah Balāgah atau yang disebut dengan retorika bahasa. Balāgah setelah menjadi ilmu, mempunyai rumusan-rumusan tertentu yang digunakan sebagai asas konkretisasi sastra dan tolak ukur keindahan dan kebalaghan karya sastra (Maulana, 2016).

Sejatinya Balāgah mencorakkan ilmu sastra di atas kajian morfologi dan sintaksis, kajian Balāgah bertumpu pada kedua ilmu tersebut, yang secara teori prasyarat menelaah Balāgah 
harus menguasai gramatika bahasa yang merupakan pembahasan tentang morfologi dan sintaksis. Dalam gramatika bahasa Arab dikenal istilah Nahwu yang pararel dengan sintaksis, dan Șarf yang pararel dengan morfologi (Burdah, 2004).

Untuk mengungkapkan keelokan bahasa Al-Qur'an, banyak instrumen ilmu yang dibutuhkan, di antara ilmu yang terpenting adalah ilmu Balāgah. Hal ini dikatakan oleh Al Jarim dan Amin (2015), bahwa Ilmu Balāgah adalah suatu disiplin ilmu yang berdasarkan kepada kejernihan jiwa, ketelitian menangkap keindahan dan kejelasan perbedaan yang samar di antara macam-macam uslub (ungkapan). Al-Qur'an memiliki tingkat fashahat dan Balāgah yang tinggi, sehingga untuk memahaminya haruslah betul-betul memahami ilmu Balāgah. Banyak yang dibahas dalam ilmu Balāgah khususnya pada ilmu ma'ānī salah satunya struktur kalimat amr (perintah).

Ihwal Amr sebagaimana diketahui, $a m r$ ialah suatu perkataan atau pertuturan yang dipakai oleh orang yang lebih tinggi derajatnya untuk menuntut kepada orang yang lebih rendah derajatnya agar melakukan suatu perbuatan (Hamka, 2017). Sekaitan dengan definisi $a m r$ ada yang berpendapat bahwa $a m r$ adalah lafaz yang menunjukkan makna suruhan yang mana melakukan tindakan di waktu yang akan datang (Hakim, 2014).

Bertemali perihal kalimat Chaer (2009) menandaskan bahwa kalimat itu beragam jenisnya, yaitu kalimat perintah, kalimat tanya, kalimat berita, dan sebagainya. Kalimat perintah dilihat dari taraf reaksi tindakan yang diharapkan dibedakan adanya (a) kalimat perintah yang tegas, (b) kalimat perintah yang biasa, dan (c) kalimat perintah yang halus.

Menurut Syatibi (2013) Jika kalimat perintah amr ditinjau dari pandangan ilmu Balāgah. Menyulut banyak arti. Di antaranya, kalimat perintah permintaan (doa), kalimat perintah memberi saran, kalimat perintah setara (sederajat kedudukannya), kalimat perintah anganangan (seuatu yang tidak mungkin tercapai), kalimat perintah memilih (memberi pilihan), kalimat perintah menyamakan, kalimat perintah melemahkan, kalimat perintah mengancam, dan kalimat perintah membolehkan.

Jenis kalimat perintah (memberi saran) ditemukan dalam terjemahan Al-Qur'an H.B. Jassin (HBJ) surah Yāsīn pada ayat ke 13.

Terjemahan HBJ (1982)

Dan buatlah perumpamaan bagi mereka, (Suatu kisah) penduduk negri, Ketika datang Rasulrasul kepada mereka. 
Jenis kalimat perintah (memberi saran) maksudnya adalah bahwa bentuk kalimat perintah itu, tidak dimaksudkan sebagai perintah, tetapi mengarah sebagai saran yang diungkapkan mutakallim dan kepada mukhatab. Ihwal penerjemahan Al-Qur'an sejatinya sudah banyak dilakukan di antaranya: Al-Qur'an dan Terjemahnya (terjemah Kemenag), AlQur'anul Karim Tarjamah Tafsiriyah karya Muhammad Thalib, terjemahan Al-Qur'an \& Maknanya karya M. Quraish Shihab, terjemahan tafsir Al-Quran karya Mahmud Yunus dan lain sebagainya.

Banyak referensi yang dapat digunakan ketika kita ingin memafhumi arti dari penerjemahan. Secara umum, penerjemahan dapat diartikan sebagai cara pengalihan pesan dari bahasa sumber (BS) ke bahasa target (BT). Menurut Larson (1984), penerjemahan didefinisikan sebagai suatu aktivitas pengalihan BS ke BT.

Sementara itu, Newmark (1988) mengemukakan bahwa "translation in rendering the meaning of a text into another language in the way that the author intended the text". Newmark memberikan pemahaman mengenai pengalihan pesan dalam kegiatan penerjemahan. Dalam kegiatan penerjemahan, seorang penerjemah harus mengetahui tujuan penulis teks asli BS.

Dengan kata lain, penerjemahan bukan hanya suatu proses pengalihan bahasa saja tetapi juga merupakan cara pengalihan ide, pikiran atau gagasan dari BS ke BT, baik secara tertulis, maupun ujaran. Dalam menerjemahkan suatu teks, seorang penerjemah kerap menemui kesukaran yang bertalian dengan variasi linguistik dan budaya yang terdapat dalam BS dan BT. Kesukaran tersebut dapat ditangani dengan menggunakan strategi penerjemahan. Menurut Lorscher (2005), strategi penerjemahan merupakan prosedur untuk menyempurnakan masalah terjemahan. Mulai dari realisasi masalah penerjemahan hingga penyelesaiannya atau realisasi tidak dapat dipecahkannya oleh subjek pada saat tertentu.

Terjemahan yang dihasilkan sesungguhnya tidak melekang dari metode penerjemahan yang digunakan. Metode penerjemahan ialah pilihan yang bersifat umum. Menurut Al farisi (2013) pemilihan metode penerjemahan turut menetukan corak dan warna teks terjemahan secara keseluruhan. Selain metode ada yang lebih penting yaitu teknik penerjemahan, lebih lanjut, Molina \& Albir (2002) mendefinisikan teknik penerjemahan sebagai prosedur untuk menganalisis dan mengklasifikasikan bagaimana keekuivalenan terjemah berlangsung dan dapat diterapkan pada berbagai satuan lingual kata, frasa, klausa maupun kalimat.

Penelitian tentang amr imperatif Al Farisi (2017) melakukan penelitian dia mengungkapkan ketedasan terjemahan ayat-ayat imperatif bernuansa budaya. Sampel 
penelitiannya dipilih secara purposive berupa ayat-ayat imperatif memiliki makna pragmatik tertentu. Sejatinya ketedasan terjemahan ayat-ayat imperatif tidak terlepas dari teknik dan prosedur penerjemahan yang diterapkan dalam mengatasi unit-unit mikro terjemahan. Korpus penelitian yang dipakai mengunakan Al-Qur'an Terjemah Kemenag.

Selanjutnya penelitian tentang amr imperatif juga dilakukan oleh Nurdianti (2018). Dia mengunakan terjemahan Al-Qur'an pada surah Al-Waqi'ah. Penelitiannya menunjukkan bahwa dalam terjemahan Al-Quran surah Al-Waqi'ah ditemui bentuk tuturan imperatif. Bentukbentuk yang didapat ialah bentuk tuturan imperatif dalam kalimat deklaratif, introgatif, imperatif, dan eksklamatif.

Penelitian serupa yang dilakukan oleh Imran (2018) al-amr akan tetapi dalam QS AlTaubah analisis perspektif ilmu al-ma'ānī. Ia hanya menguraikan serta menjelaskan bentuk sigah al-amr dalam QS Al-Taubah dan makna al-amr dalam perspektif ilmu al-ma'ānī. Dari ketiga penelitian disebutkan, sesungguhnya terdapat rumpang (gap) penelitian yang belum diteliti yaitu tentang analisis kalimat perintah $(a m r)$ pada surah Yāsīn dalam terjemahan AlQur'an Bacaan Mulia Karya HBJ.

Peneliti meneliti variasi kalimat, yaitu kalimat perintah dilihat dari tinjauan ilmu Balāgah pada terjemahan Al-Qur'an HBJ surah Yāsīn. Sebab, dalam surah tersebut ditemukan beberapa data berupa kalimat perintah. Peneliti memilih Terjemahan Al-Qur'an HBJ sebagai objek penelitian lantaran dilihat dari latar belakang penerjemah Al-Qur'an tersebut, penerjemahnya adalah seorang yang bukan seorang ahli tafsir Al-Qur'an melainkan ahli dalam bidang ilmu sastra. Terjemahan Al-Qur'annya pun berbeda dengan terjemahan Al-Qur'an yang ada. Terjemahannya bercorak puisi.

\section{METODE}

Penelitian ini menggunakan metode deskriptif kualitatif dengan model analisis isi. Pemilihan metode ini didasarkan pada karakteristik dan spesifik permasalahan yang akan ditelaah terkait dengan terjemahan kalimat perintah amr dalam surah Yāsīn. Metode deskriptif kualitatif dengan model analisis isi (content analysis) ini dianggap relevan karena penelitian ini menitik beratkan pada hasil karya terjemahan. Selain itu, peneliti mendesripsikan masalah tersebut sehingga menyampaikan kejelasan terhadap objek yang diteliti.

Penelitian ini terbatas pada usaha mengungkapkan suatu masalah dan keadaan sebagimana adanya, sehingga hanya ada pengungkapan fakta, sesuai dengan data yang ada, sehingga mencapai maksud dan tujuan penelitian. Tujuan penelitian ini untuk mengungkapkan 
seberapa banyakkah bentuk perintah amr dalam surah Yāsīn, dan teknik penerjemahan apa sajakah yang digunakan oleh HBJ.

Data yang peneliti ambil ini terdiri dari sumber primer dan sekunder. Sumber primer atau sumber utama yang peneliti ambil ialah Surah Yāsīn yang terdapat dalam Al-Qur'an Terjemahan Bacaan Mulia HBJ. Sedangkan sumber sekunder atau pendukung dari literatur Balāgah, teori-teori penerjemahan, tafsir al-Lubāb, Tafsir Hamami, serta sumber literatur lainnya sebagai pendukung.

Secara teknis, yang peneliti lakukan yaitu dengan membatasi korpus yang akan diambil. Setelah itu membacanya secara keseluruhan, kemudian menentukan berapa banyak struktur $a m r$ dalam surah Yāsīn. Pada bagian analisis data, peneliti akan menentukan sempalan ayatayat dari surah Yāsīn yang mengandung struktur perintah amr. Langkah selanjutnya menganalisis terjemahan Al-Qur'an bacaan mulia karya HBJ, dilihat dari teknik penerjemahan apa sajakah yang digunakan oleh HBJ.

\section{HASIL DAN PEMBAHASAN}

Berdasarkan paparan data terjemahan struktur kalimat perintah ( $a m r$ ) yang terdapat dalam surah Yāsīn secara rinci, peneliti perlu meguraikan eksistensi bentuk-bentuk amr itu sendiri di dalam surah yang sedang dibahas ini. Bentuk Amr yang terdapat dalam surah Yāsīn sebanyak 12, tersebar dalam 12 ayat.

Bentuk amr yang sebanyak 12 tersiar dalam ayat-ayat sebagai berikut: 11, 13, 20, 21, 25, 26, 45, 47, 61, 64,79 dan 82. Seluruhnya berbentuk fi'il Amr. Adapun bentuk fi'il muḍāri' yang didahului lam amr, bentuk masdar pengganti fi'il amr, dan bentuk isim fi'il amr tidak ditemukan dalam surah Yāsīn. Dari 12 amr dalam surah Yāsīn amr bermakna haqĩqi terdapat tujuh ayat. Sedangkan amr bermakna balāgi terdapat lima ayat, yang tercandarakan keduanya dalam tabel berikut ini.

\begin{tabular}{|c|c|c|c|}
\hline Ayat & Amr Haqīqi dalam Surat Yāsīn & ayat & Amr Balāgi dalam Surat Yâsîn \\
\hline 11 & فَبَثَتِّهُهُ & 13 & وَاضْرِبْ \\
\hline 26 & اذْخُلِ & 20 & اتَبَّعُوا \\
\hline 45 & اتَّقُوا & 21 & انتِبَعُوا \\
\hline 61 & اعْبُدُوِين & 25 & فَاسْمَعَوِنِ \\
\hline 64 & اصْلَوْهَا & 47 & أَنْفْقُوا \\
\hline
\end{tabular}


79

82

Sedangkan teknik penerjemahan kalimat perintah amr yang digunakan oleh penerjemah HBJ tergambarkan dalam diagram berikut ini.

\section{Teknik Penerjemahan Surah Yāsīn}

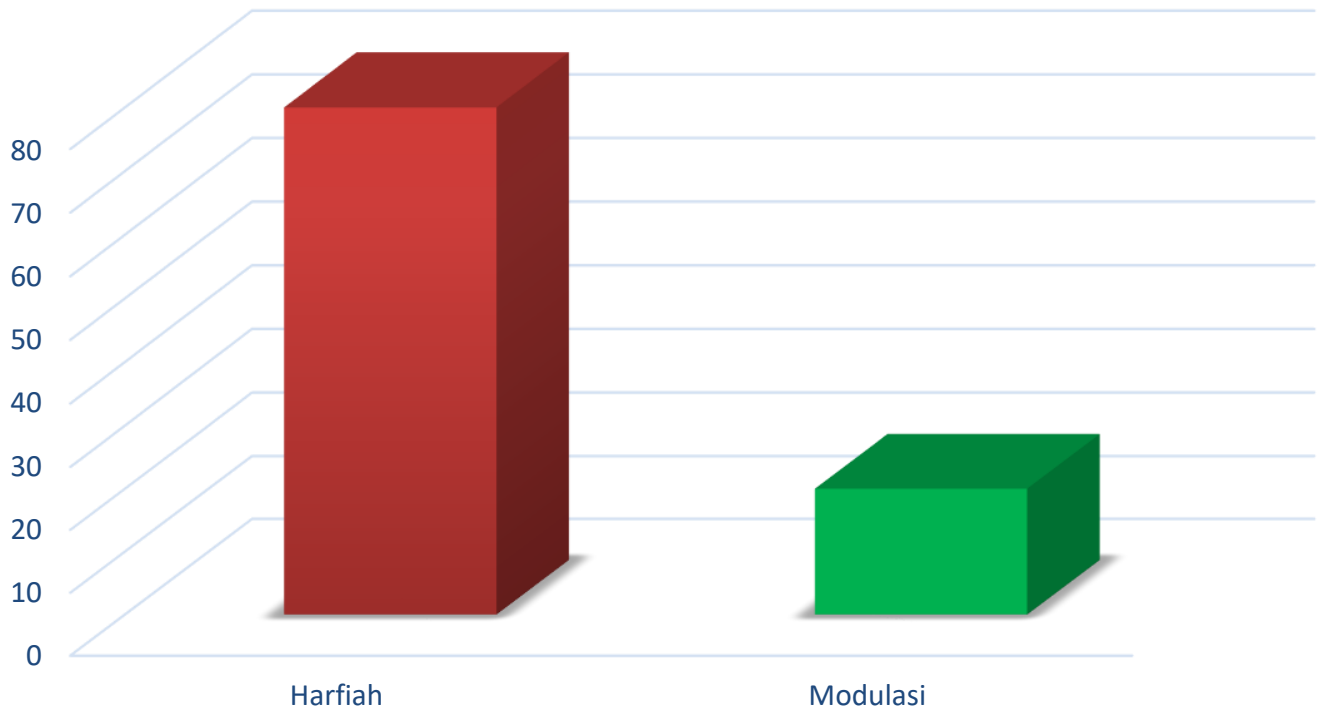

\section{Makna dan Analisis Amr Haqĩqi dalam Surah Yāsīn.}

Peneliti menemukan makna-makna amr haqìqi dalam surah Yāsīn sebanyak tujuh ayat, tersebar pada ayat ke $11,26,45,61,64,79$, dan 82 .

\section{Ayat: 11}

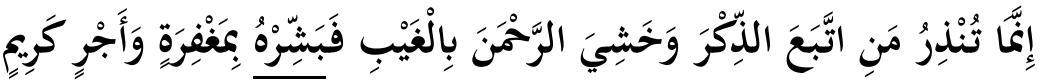

\section{Terjemahan HBJ}

Kau hanya dapat memberi peringatan pada orang yang mengikuti peringatan dan takut kepada (Tuhan) yang maha Pemurah, (walaupun) ia tiada melihat-Nya. Maka sampaikanlah kabar gembira tentang ampunan dan pahala berlimpah.

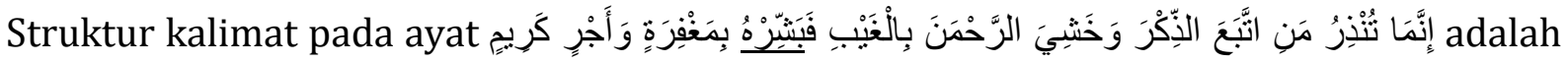

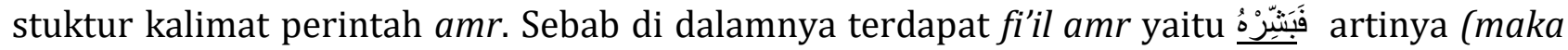
sampaikanlah kabar gembira). Mutakallim adalah Allah, sedangkan Mukhātab-nya adalah Nabi 
Muhammad Saw. Sebagai Mutakallim, derajat Allah lebih tinggi daripada Nabi Muhammad Saw

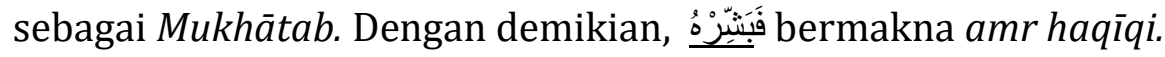

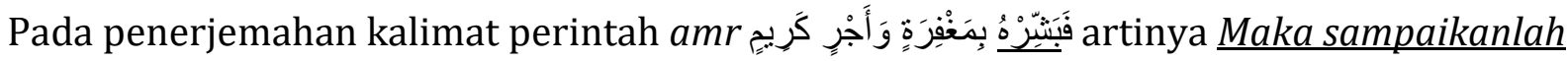
kabar gembira tentang ampunan dan pahala berlimpah. Data tersebut menunjukkan penggunaan teknik penerjemahan harfiah dalam menangani frasa فَفَبَّرْْْ yang diterjemahkan menjadi Maka sampaikanlah kabar gembira. Selaras dengan pernyataan Molina \& Albir (2002), teknik penerjemahan harfiah merupakan teknik penerjemahan kata atau ungkapan secara kata perkata.

Ayat: 26

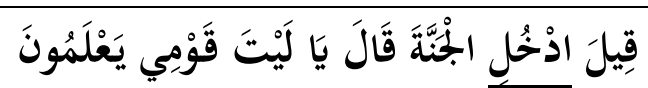

Terjemahan HBJ

Dikatakan (kepadanya), “masuklah sorga." Ia menjawab, Aduhai, sekiranya kaumku tahu.

disebut stuktur kalimat perintah amr. Sebab, di frasa tersebut terdapat fi'il amr yaitu إدخُل artinya (masuklah). Mutakallim adalah para malaikat. sedangkan Mukhātab-nya adalah Habib an-Najjar (sang syahid). Sebagai Mutakallim, taraf tingkatan para malaikat lebih tinggi daripada Habib an-Najjar (sang syahid) sebagai Mukhātab. Dengan demikian, ادْخُل bermakna amr haqīqi.

Demi memperkuat argumen tentang struktur kalimat perintah $(a m r)$ bermakna $a m r$ haqīqi pada ayat ke 26 di surah Yāsīn. Peneliti tampilkan tafsir al-Lubāb surah Yāsīn karangan M. Quraish Shihab pada ayat ke 26. Yakni: dikatakan kepada mereka, yakni oleh para malaikat: "Masuklah ke surga" yakni bergembiralah dengan surga yang akan engkau masuki kelak atau nikmatilah kenikmatan surgawi dan alam kubur, sebelum kenikmatan surga yang akan engkau masuki setelah kebangkitan dari dari kubur nanti. Mendengar kabar berita gembira itu, sang sahid berkata: “ alangkah baiknya sekiranya kaumku mengetahui” yang sedang kualami ini.

Teknik penerjemahan kalimat perintah amr pada قِيَل ادْخُلِ الْجَنَّنَ artinya Dikatakan (kepadanya), "masuklah sorga." Pada frasa اذْخُل artinya masuklah, jika diamati pada frasa tersebut menggunakan teknik penerjemahan harfiah. Ini Molina \& Albir, (2002) yang menyebutkan penggunaan teknik penerjemahan harfiah, teknik penerjemahan kata atau ungkapan secara kata perkata.

\section{Ayat: 45}




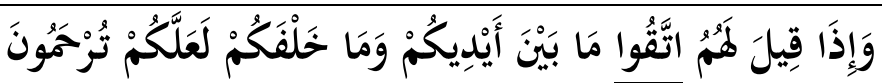

Terjemahan HBJ

Dan bila dikatakan kepada mereka, "Takutlah kamu akan (azab) yang ada di depan kamu, Dan (azab) yang akan datang, Supaya kamu mendapat rahmat," (Mereka berbalik kebelakang).

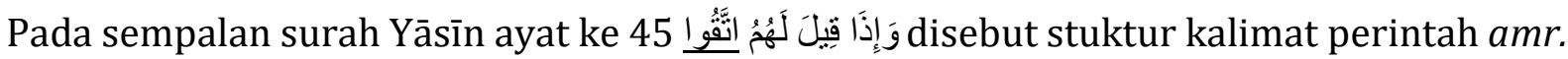

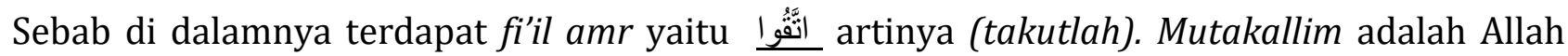
sedangkan Mukhātab-nya adalah orang-orang musyrik. Sebagai Mutakallim, kedudukan Allah

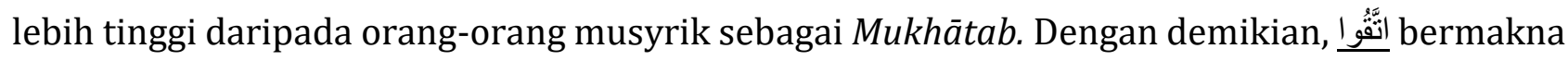
amr haqīqi.

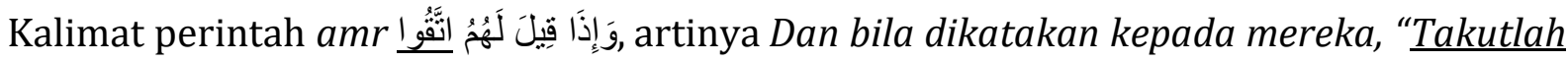
kamu akan (azab), data tersebut menunjukkan penggunaan teknik harfiah dalam menangani frasa

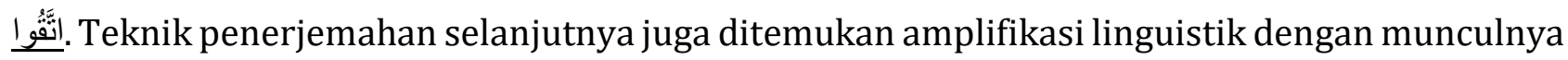
terjemahan "akan (azab)", senada dengan penjelasan Molina \& Albir (2002). Bahwa amplifikasi linguistik adalah teknik penerjemahan penambahan elemen linguistik sehingga terjemahnya lebih panjang.

Ayat: 61

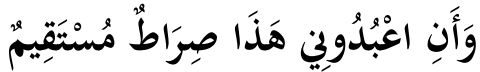

Terjemahan HBJ

Tapi menyembah aku, (karena) inilah jalan yang lempang.

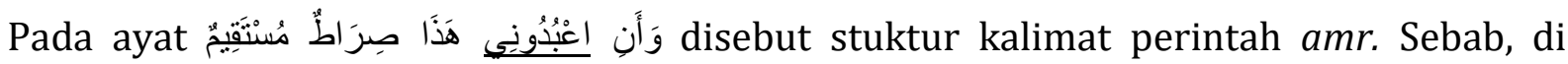
dalamnya terdapat fi'il amr yaitu اعْبُدُوني artinya (menyembah aku). Mutakallim adalah Allah sedangkan Mukhātab-nya adalah orang-orang musyrik kepada Allah. Sebagai Mutakallim, derajat Allah lebih tinggi daripada orang-orang musyrik sebagai Mukhātab. Dengan demikian اعْبُدُوني bermakna amr haqīqi.

Pada penggalan ayat 61 yang berbunyi وَأَنِ اعْبُدُونِي artinya Tapi menyembah aku, data tersebut menunjukkan teknik penerjemahan harfiah. Sebab pada frasa اعْبُدُوني diterjemahkan

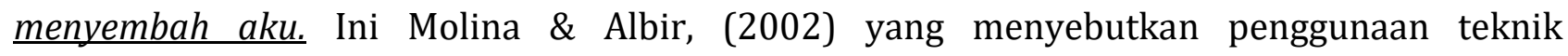
penerjemahan harfiah, teknik penerjemahan kata atau ungkapan secara kata perkata.

\section{Ayat: 64}


Terjemahan HBJ

Masuklah kedalamnya hari ini, karena kamu mengingkari kebenaran.

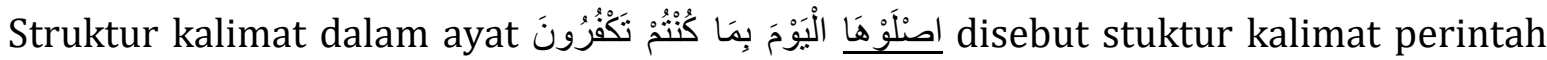

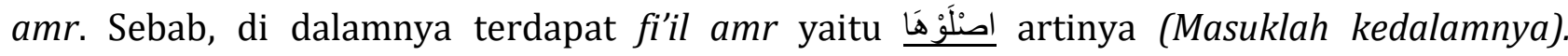
Mutakallim adalah Allah sedangkan Mukhātab-nya adalah orang-orang kafir kepada Allah. Sebagai Mutakallim, level Allah lebih tinggi daripada orang-orang kafir sebagai Mukhātab. Dengan demikian, اصنَلْوَهَ bermakna amr haqĩqi. Selanjutnya teknik penerjemahan pada frasa اصِنْوَهَ yang diterjemahkan (Masuklah kedalamnya). HBJ menggunakan teknik harfiah.

Ayat: 79

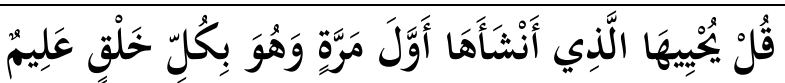

Terjemahan HBJ

Jawablah, "Yang memberinya hidup, Itulah Penciptanya yang pertama kali Dan ialah yang mengetahui segala kejadian!

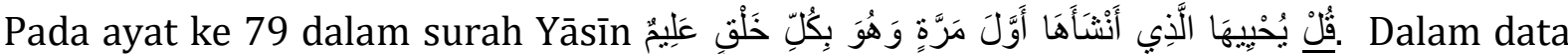
tersebut terdapat fi'il amr yaitu قُّ artinya (Jawablah). Mutakallim adalah Allah sedangkan Mukhātab-nya adalah Nabi Muhammad Saw. Sebagai Mutakallim, posisi Allah lebih tinggi daripada Nabi Muhammad Saw. sebagai Mukhātab. Dengan demikian, فُقْ bermakna amr haqīqi.

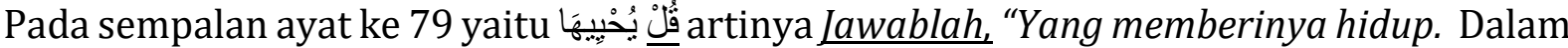
data tersebut terdapat kata قُّ yang diterjemahkan jawablah. Data tersebut menunjukkan penggunaan teknik modulasi dalam mendera pada kata قُ قُّ yang diterjemahkan menjadi

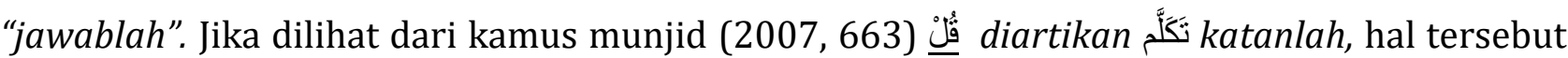
terjadi karena HBJ mengubah sudut pandang kata (2002) yang menyebutkan penggunaan teknik modulasi ialah teknik penerjemahan di mana penerjemah meminda sudut pandang, fokus atau kategori dalam kaitannya terhadap BS; bisa dalam bentuk struktural maupun leksikal.

Ayat: 82

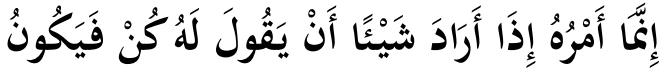

Terjemahan HBJ

Sungguh, bila Ia menghendaki seuatu, cukuplah Ia berkata, "Jadilah!” Maka iapun jadilah! 
Struktur kalimat إنَّمَا أَمْرُهُ إِذَا أَرَادَ شَيَيًَا أَنْ يَقُولَ لَهُ كُنْ فَيَكُونُ disebut stuktur kalimat perintah

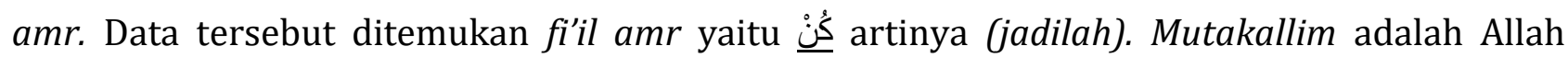
sedangkan Mukhātab-nya adalah menciptakan (sesuatu) hal baru. Sebagai Mutakallim, kedudukan Allah lebih tinggi daripada menciptakan (sesuatu) hal baru sebagai Mukhātab. Dengan demikian, كُنْ bermakna amr haqĩqi. Sedangkan teknik yang digunakan dalam menangani pada kata sُ yang artinya jadillah. HBJ memakai teknik penerjemahan harfiah.

\title{
Makna dan Analisis Amr Balāgi dalam Surah Yāsīn.
}

Peneliti menemukan makna-makna amr balāgi dalam surah Yāsīn sebanyak lima ayat, tersebar pada ayat ke 13, 20, 21, 25 dan 47.

\section{Ayat: 13}

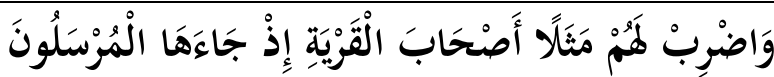

\author{
Terjemahan HBJ \\ Dan buatlah perumpamaan bagi mereka, (Suatu kisah) penduduk negri, Ketika datang Rasul- \\ rasul kepada mereka.
}

Pada ayat disebut stuktur kalimat perintah amr. Sebab di dalamnya terdapat fi'il amr yaitu وَاضْربْ artinya (dan buatlah). Kata yang bergaris bawah di atas berbentuk fi'il amr atau perintah. Namun, bentuk amr tersebut cenderung memberi saran, bukan memberi perintah. Sebab, saran yang diberikan menggunakan bentuk $a m r$, maka bentuk amr seperti ini disebut lil-irsyād atau bermakna memberi saran. Dengan demikian, وَ وَضْربْ bermakna amr balāgi.

Ihwal struktur kalimat perintah (amr) bermakna amr balāgi pada ayat ke 13 di surah Yāsīn. Peneliti hadirkan tafsir surah Yāsīn karangan Syaikh Hamami Zadah pada surah Yāsīn ayat ke 13. Yakni: Berilah mereka peringatan wahai Muhammad, dan buatlah perumpamaan hal ihwal mereka dengan cerita penduduk negeri Inthakiyyah.

Sedangkan penerjemahan kalimat perintah amr pada sempalan ayat وَ اضْرِبْ لَهُهْ مَنًََ artinya Dan buatlah perumpamaan bagi mereka, pada frasa Data tersebut menunjukkan pemakaian teknik penerjemahan harfiah dalam menangani وَاضْربْ yang diterjemahkan Dan buatlah. Senada dengan pernyataan Molina \& Albir, (2002) teknik penerjemahan harfiah merupakan teknik penerjamahan kata atau ungkapan secara kata perkata. 
Ayat: 20

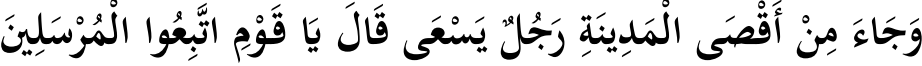

Terjemahan HBJ

Maka datang berlari-lari seorang lelaki dari ujung kota, sambil berseru, "wahai kaumku, patuhillah para utusan!

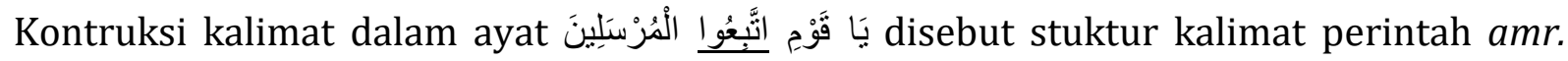
Sebab di dalamnya terdapat fi'il amr yaitu انَّبُعُو انِ artinya (patuhillah). Namun, bentuk amr di atas mengarah memberi saran, bukan memberi perintah. Sebab, saran yang berkenaan menggunakan bentuk $a m r$, maka bentuk $a m r$ seperti ini disebut li-irsyād atau bermakna

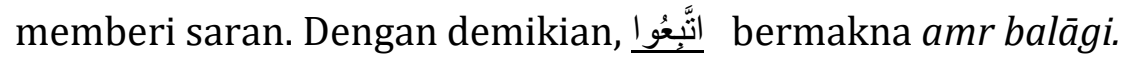

Pada sempalan ayat ke 79 dalam surah Yāsīn yaitu انََّعُو الْمُرْسَلِينَ artinya patuhillah para

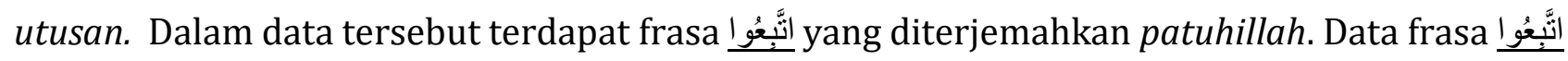
menunjukkan penggunaan teknik modulasi dalam menangani pada kata yang diterjemahkan patuhillah. Ini Molina \& Albir, (2002) yang menyebutkan penggunaan teknik modulasi merupakan teknik penerjemahan di mana penerjemah mengubah sudut pandang, fokus atau kategori dalam kaitannya terhadap BS; bisa dalam bentuk struktural maupun leksikal.

Ayat: 21

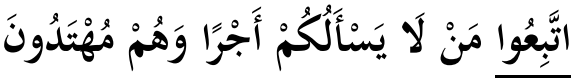

Terjemahan HBJ

"Ikutilah mereka yang tiada meminta upah dari padamu, Karena mereka beroleh bimbingan."

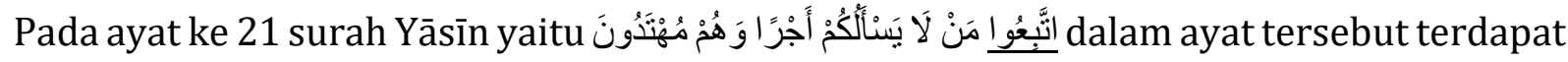
fi'il amr yaitu انَّبُعُو إن artinya (Ikutilah). Walakin, bentuk amr cenderung memberi saran, bukan memberi perintah. Sebab, saran yang diberikan menggunakan bentuk amr, maka bentuk amr seperti ini disebut li-irsyād atau bermakna memberi saran. Dengan demikian, اتَُّعْوِ bermakna

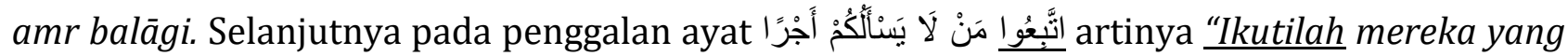
tiada meminta upah dari padamu. Pada frasa أتَّعُو إنبو yang diterjemahkan ikutillah, data tersebut menunjukkan penerjemah menggunakan teknik penerjemahan harfiah.

Ayat: 25

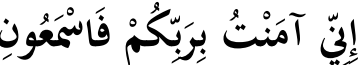

Terjemahan HBJ

Vol. 2 No. $1 \mid 1-14$

ALSUNIYAT, p-ISSN: 2615-7241, e-ISSN: 2721-480X 
"sungguh, aku beriman kepada Tuhanmu, maka dengarkanlah aku (sebagai saksi atas keimananku)!"

Struktur kalimat pada ayat إِنِي آَنْنُ بِرَبِكُمْ فَاسْمَعُونِ disebut bentuk kalimat perintah amr. Sebab, di dalamnya terdapat fi'il amr yaitu فَاسْتَعُونِ artinya (maka dengarkanlah aku). Kata yang bergaris bawah di atas berbentuk fi'il amr atau perintah. Akan tetapi, bentuk amr tersebut cenderung memberi saran, bukan memberi perintah. Sebab saran yang diberikan memakai bentuk amr, maka bentuk $a m r$ seperti ini disebut li-irsyād atau bermakna memberi saran. Dengan demikian, فَاسْنَعُون bermakna amr balāgi.

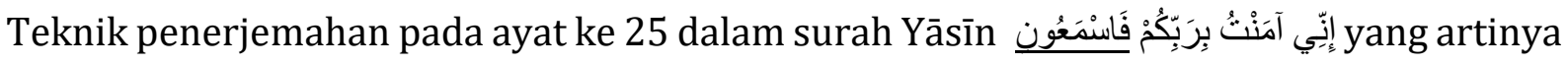
"sungguh, aku beriman kepada Tuhanmu, maka dengarkanlah aku (sebagai saksi atas keimananku)!”. Jika diamati pada frasa فَاسْمَعُون yang diterjemahkan maka dengarkanlah aku (sebagai saksi atas keimananku). Data frasa فَانْمَعُونِ menunjukkan teknik harfiah selanjutnya mengunakan teknik amplifikasi linguistik. Sebab, terdapat ungkapan tambahan yaitu "(sebagai saksi atas keimananku)". Ini selaras dengan yang diungkapkan Molina \& Albir (2002). Bahwa amplikasi linguistik adalah teknik penerjemahan penambahan elemen linguistik sehingga terjemahnya lebih panjang.

Ayat: 47

\begin{tabular}{|c|}
\hline ए ए \\
\hline $\begin{array}{l}\text { Terjemahan HBJ } \\
\text { Dan bila dikatan kepada mereka, "Nafkahkanlah sebagian pemberian Allah kepadamu," Orang } \\
\text { yang kafir mengejek kepada orang yang beriman, "akankah kami beri makan orang Yang } \\
\text { Tuhan herimakan Sekiranva Ia herkenan? Kamu hanva dalam kesesatan vana nvata }\end{array}$ \\
\hline
\end{tabular}

Pada penggalan ayat وَإِذَا قِيَلَ لَهُمْ أَنَفْقُو disebut stuktur kalimat perintah amr. Sebab, dalam

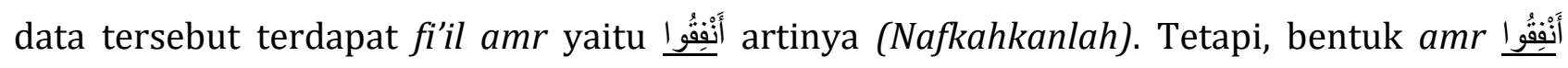
cenderung memberi saran, bukan memberi perintah. Sebab saran yang diberikan menggunakan bentuk amr. Oleh karena itu, bentuk amr seperti ini disebut li-irsyād atau bermakna memberi saran. Dengan demikian أَنْفُقُ bermakna amr balāgi

Pada ayat وَإِذَا قِيلَ لَهُمْ أَنْفُقو artinya Dan bila dikatan kepada mereka, "Nafkahkanlah. ditemukan frasa yaitu 1 أَنْقُقُ diterjemahkan “Nafkahkanlah. Data tersebut menunjukkan teknik penerjemahan harfiah, senada dengan yang diungkapakan oleh Molina \& Albir, (2002) yang 
menyebutkan penggunaan teknik penerjemahan harfiah, teknik penerjemahan kata atau ungkapan secara kata perkata.

\section{SIMPULAN}

Dari hasil penelitian terhadap terjemahan Al-Qur'anul Karim Surah Yāsīn Bacaan Mulia karya HBJ, peneliti menyimpulkan bahwa bentuk fi'il amr saja yang ditemukan dalam surah tersebut. Sedangkan fi'il muḍāri' yang didahului lam amr, bentuk masdar pengganti fi'il amr, dan bentuk ism fi'il amr tidak ditemukan dalam surah Yāsīn. Lebih lanjut, jika dilihat dari teknik penerjemahan oleh HBJ. Bedasarkan pengamatan peneliti lakukan, teknik penerjemahan harfiah yang mendominasi berjumlah 10 ayat yang digunakan oleh HBJ. Sedangkan teknik modulasi peneliti hanya menemukan dua ayat saja yaitu pada ayat 20 dan 79 .

\section{DAFTAR PUSTAKA}

Al Farisi, M. Z. (2013). Aspek Relevansi dalam Terjemahan Tindak-Tutur Kinayâh Al-Qur'an. Jurnal Karsa. 21(2). 161-174.

Al Farisi, M. Z. (2017). Ketedasan Terjemahan Ayat-Ayat Imperatif Bernuansa Budaya. Jurnal El Harakah 19(2). 159-176.

Al Jarim, A \& Amin, M. (2015). Terjemahan Al-Balaghatul Waadhihah. Bandung: Sinar Baru Algensindo.

Almunjid fi al-lughah wa al-a'lām, (2007). Lubnan. Dar el-Machreq sarl Publishers.

Burdah, I. (2004). Menjadi Penerjemah Metode dan Wawasan Menerjemah Teks Arab. Yogyakarta: Tiara Wacana Yogya.

Chaer, A. (2009). Sintaksis Bahasa Indonesia (Pendekatan Proses). Jakarta: PT Rineka Cipta.

Hakim, S. (2014). Problematika Bentuk Amar dan Pengaruhnya Terhadap Istimbat Fiqh. Jurnal Al-Hikmah. 4(1). 53-60.

Hamka, H. Z. (2017). Kaidah-Kaidah Tafsir yang Berhubungan dengan Amr (Perintah) dan Nahy (Larangan) di dalam Al-Qur'an. Jurnal Ash-Shahabah. 3(2). 178- 189.

Imran. (2018). Al-Amr dalam QS Al-Taubah (Analisis Perspektif Ilmu Ma'ānī). Jurnal Diwan. 4(2). 123-138.

Jassin, H.B. (1982). Al-Qur'anul Karim Bacaan Mulia. Jakarta: Yayasan 23 Januari 1942.

Larson, M. L. (1984). Meaning-Based Translation A Guide to Cross-Language Equivalence. $2^{\text {nd }}$ Ed. New York: University Press Of America. 
Lorscher, W. (2005), The Translation Process: Methods and Problems of its Investigation. Jurnal Meta. 2. 598-608.

Maulana, D. (2016). Struktur Kalimat Perintah (Amr) dalam Surat Yāsīn, (Studi Kasus dalam terjemahan kalam Mulia Oleh H.B. Jassin). Skripsi. UIN Jakarta.

Molina, L. \& Albir H. (2002). Translation Techniques Revisited: A Dinamic and Functionalist Approach. Jurnal Meta. 47(4). 498-512.

Newmark, P. (1988). A Text Book of Translation. London: Practice Hall.

Nurdianti, I. (2018). Bentuk tuturan Imperatif pada Terjemahan Al Quran Surat Al-Waqi'ah. Skripsi. Universitas Muhammadiyah Purwokerto.

Sihab, M.Q. (2012). AL-LUBÂB makna, Tujuan, dan Pelajaran dari Surah-surah al-Qur'an. Tanggerang: Lentera Hati.

Syatibi, A. (2013). Balāgah II (Ilmu Ma'ani) Pengantar Memahami Makna Al-Qur'an. Jakarta: Tarjamah Center.

Zadah, H. (2014). Tafsir Surat Yâsîn. Surabaya: Mutiara Ilmu. 